The results of maceral group analysis and rank determination under the microscope have also been obtained for five coal samples. The samples are very rich in vitrinite and poor in inertinite. The content of separated minerals at a density of $1.9 \mathrm{~g} / \mathrm{ml}$ is high. The rank determinations were made by measuring the averange reflectance on vitrinites. The range of reflectance values is between $0.42 \%$ and $0.49 \% R_{\mathrm{m}}$.

The preliminary chemical analyses and petrographic studies suggest that the coal of Nûgssuaq is of low rank, high volatile, bituminous $C$ variety.

\title{
References
}

Frandsen, N. \& Shekhar, S. C. 1980: Coal in West Greenland. Rapp. Grønlands geol. Unders. 100, 49-51.

Rosenkrantz, A. 1970: Marine Upper Cretaceous and lowermost Tertiary deposits in West Greenland. Meddr dansk geol. Foren. 19, 406-453.

\section{Chromium-rich sapphirine from the Bjørnesund area, southern West Greenland and its bearing on the conditions of crystallisation of the Fiskenæsset anorthosite complex}

\section{R. L. Friend and D. J. Hughes}

Windley et al. (1973) have postulated that the Fiskenæsset anorthosite complex crystallised under conditions of high water vapour pressure. This hypothesis readily explains several of the distinct characteristics of the complex. In particular, the late precipitation of chromitite layers towards the top of the complex in the anorthosite sensu stricto (Ghisler \& Windley, 1967) is not normally expected in large layered intrusions (Wager \& Brown, 1968), and is explained because the early precipitation of chromite is suppressed under such conditions (Shiraki, 1966). Also, Windley et al. (1973) have suggested that chromium amphibole, rather than pyroxene, was precipitated in association with the chromite as a direct consequence of the enrichment of volatiles in the upper parts of the intrusion.

During the mineralogical investigation of samples collected from a site north of Bjørnesund (Fig. 14), at the intrusive, upper contact of the Fiskenæsset anorthosite complex with supracrustal rocks which contain aluminous ultramafic bodies (Friend \& Hughes, 1977), evidence has come to light which directly supports the elevated water vapour pressure hypothesis.

At this locality, where the aluminous ultramafic rocks are in contact with and engulfed by the intrusive anorthosite, a reaction has occurred to give an extensive development of the Mg-Al-rich minerals sapphirine and kornerupine. The sample GGU 149434 was selected for investigation because it contains purple and maroon colour-zoned sapphirine, with 


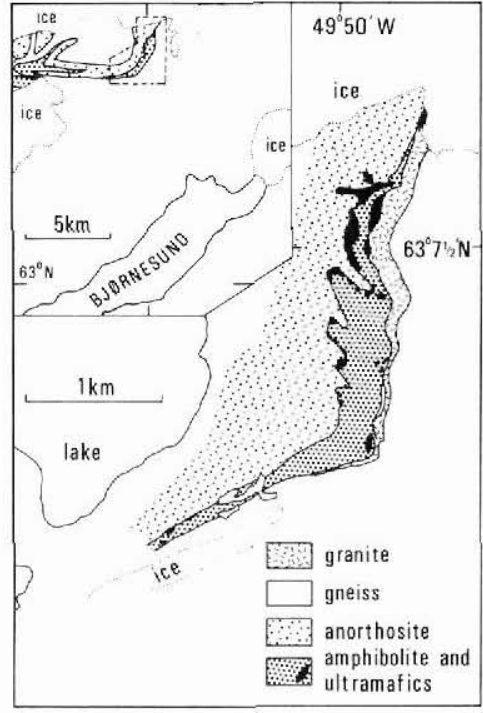

Fig. 14. Simplified geological map of the contact zone showing the location of GGU 149434 (arrow) and the ultramafic bodies. Inset. Location of the intrusive anorthosite contact and the reaction rocks north of Bjørnesund. Key is the same as the main figure.

rounded inclusions of ruby corundum and red spinel, co-existing with apple-green amphibole. Plates of phlogopite and minor amounts of opaque iron oxide complete the mineral assemblage. This rock is thought to have developed by the reaction of the aluminous ultramafic rocks and the anorthosite magma (Friend \& Hughes, 1977). The ultramafic rocks away from the contact, which have not reacted, have been the subject of mineral and whole-rock chemical studies and have been found to contain relatively low amounts of $\mathrm{Cr}_{2} \mathrm{O}_{3}$. It would be expected, therefore, that if the aluminous, $\mathrm{Cr}$-poor ultramafic material had reacted with anorthosite magma under conditions of low water vapour pressure, $\mathrm{Cr}_{2} \mathrm{O}_{3}$ should be a minor constituent in the minerals resulting from this reaction. The analyses presented in Table 4 show that this is not the case. The sapphirines, which are the most $\mathrm{Cr}$-rich sapphirines yet reported in the literature, are accompanied by chrome-rich magnesio-cummingtonite (using the new amphibole nomenclature of Leake, 1978), chrome-corundum, chrome-rich magnesium spinel and chrome-bearing phlogopite. The $\mathrm{Cr}_{2} \mathrm{O}_{3}$ content of these mineral phases accounts for their unusually strong coloration. It follows, therefore, that $\mathrm{Cr}_{2} \mathrm{O}_{3}$ has been acquired during the reactions forming the new mineral assemblage. The implications of this are that the source of the $\mathrm{Cr}_{2} \mathrm{O}_{3}$ was the anorthosite magma with which the aluminous ultramafic rocks were reacting.

This supports the suggestion of Windley et al. (1973) that if the water vapour pressure was high during the time of the emplacement of the anorthosite magma $\mathrm{Cr}^{3+}$ was prevented from participating in any of the crystallising mineral phases. Therefore, $\mathrm{Cr}^{3+}$ would be preferentially retained in the liquid to precipitate out late in the massive chromitites contained in the anorthosite unit towards the top of the intrusion. This would allow the aluminous ultramafic rocks at the upper contact which were reacting with the volatiles to pick up $\mathrm{Cr}^{3+}$ from the magma as crystallisation proceeds. This process will be enhanced if the minerals which were forming have suitable sites available for occupation by $\mathrm{Cr}^{3+}$. In the aluminous ultramafic rocks the mineral that is reacting to give rise to the sapphirine is an $\mathrm{Mg}-\mathrm{Al}$ spinel (Friend \& 
Table 4. Representative electron-microprobe analyses of $\mathrm{Cr}_{2} \mathrm{O}_{3}$-rich sapphirine and coexisting mineral phases from a

sapphirine-magnesio-cummingtonite-corundum-spinel-phlogopite rock from north

of Bjørnesund, Fiskenasset region

\begin{tabular}{|c|c|c|c|c|c|c|c|c|c|c|c|c|c|c|c|c|c|c|}
\hline & \multicolumn{5}{|c|}{ Sapphirine } & \multicolumn{4}{|c|}{ Magnesio-cummingtonite } & & \multicolumn{2}{|c|}{ Phlogopite } & \multicolumn{3}{|c|}{ Spinels } & & \multicolumn{2}{|c|}{ Corundum } \\
\hline & 2 & 10 & 13 & 29 & 30 & & 1 & 10 & 11 & & 1. & 3 & & 1 & 2 & & 3 & 5 \\
\hline $\mathrm{SiO}_{2}$ & 11.7 & 11.9 & 11.0 & 12.3 & 11.40 & $\mathrm{SiO}_{2}$ & 46.7 & 48.3 & 47.5 & $\mathrm{SiO}_{2}$ & 40.8 & 39.1 & $\mathrm{SiO}_{2}$ & n.d. & 0.17 & $\mathrm{SiO}_{2}$ & n.d. & n.d. \\
\hline $\mathrm{Al}_{2} \mathrm{O}_{3}$ & 63.2 & 60.7 & 63.6 & 60.9 & 61.70 & $\mathrm{TiO}_{2}^{2}$ & 0.15 & 0.12 & 0.16 & $\mathrm{TiO}_{2}$ & 1.80 & 0.65 & $\mathrm{Al}_{2} \mathrm{O}_{3}$ & 47.2 & 46.90 & $\mathrm{Al}_{2} \mathrm{O}_{3}$ & 94.9 & 97.30 \\
\hline $\mathrm{Cr}_{2} \mathrm{O}_{3}$ & 5.16 & 7.11 & 5.58 & 6.43 & 7.40 & $\mathrm{Al}_{2} \mathrm{O}_{3}$ & 18.0 & 17.5 & 17.0 & $\mathrm{Al}_{2} \mathrm{O}_{3}$ & 17.3 & 18.1 & $\mathrm{Cr}_{2} \mathrm{O}_{3}$ & 26.3 & 26.80 & $\mathrm{Cr}_{2}^{2} \mathrm{O}_{3}$ & 4.66 & 2.98 \\
\hline $\mathrm{FeO} *{ }^{3}$ & 0.50 & 0.55 & 0.49 & 0.69 & 0.91 & $\mathrm{Cr}_{2} \mathrm{O}_{3}$ & 1.22 & 1.28 & 0.88 & $\mathrm{Cr}_{2} \mathrm{O}_{3}$ & 0.96 & 0.70 & $\mathrm{FeO} \star^{3}$ & 4.08 & 4.26 & & $\overline{99.56}$ & 100.28 \\
\hline Mno & n.d. & n.d. & 0.13 & n.a. & 0.15 & $\mathrm{FeO} * 3^{3}$ & 1.30 & 1.23 & 1.35 & $\mathrm{FeO} 0^{3}$ & 0.53 & 0.53 & Mno & n.d. & 0.18 & & & \\
\hline \multirow[t]{3}{*}{$\mathrm{MgO}$} & 19.0 & 19.2 & $\underline{18.6}$ & 19.6 & 18.60 & $\mathrm{MgO}$ & 27.0 & 27.0 & 27.4 & $\mathrm{MgO}$ & 25.0 & 23.6 & $\mathrm{MgO}$ & 22.7 & 22.70 & & & \\
\hline & $\overline{99.56}$ & $\overline{99.36}$ & $\overline{99.40}$ & 99.92 & $\overline{100.16}$ & $\begin{array}{l}\mathrm{NiO} \\
\mathrm{CaO}\end{array}$ & $\begin{array}{l}\text { n.d. } \\
0.48\end{array}$ & $\begin{array}{l}0.14 \\
0.66\end{array}$ & $\begin{array}{l}\text { n.d. } \\
0.57\end{array}$ & $\begin{array}{l}\mathrm{NiO} \\
\mathrm{CaO}\end{array}$ & $\begin{array}{l}\text { n.d. } \\
0.10\end{array}$ & $\begin{array}{l}\text { n.d. } \\
0.09\end{array}$ & & 100.28 & $\frac{2.00}{101.01}$ & & & \\
\hline & & & 20101 & & & $\mathrm{Na}_{2} \mathrm{O}$ & $\begin{array}{l}0.48 \\
1.21\end{array}$ & $\begin{array}{l}0.60 \\
1.47\end{array}$ & $\begin{array}{l}0.57 \\
1.30\end{array}$ & $\mathrm{Na}_{2} \mathrm{O}$ & 0.84 & $\begin{array}{l}0.09 \\
0.95\end{array}$ & & & $32(0)$ & & & \\
\hline Si & 1.371 & 1.414 & 1.302 & 1.444 & 1.348 & $\mathrm{~K}_{2} \mathrm{O}$ & $\frac{\pi . d}{0.0}$ & $\frac{n . d .}{0.5}$ & $\frac{n . d_{1}}{0.0}$ & $\mathrm{~K}_{2} \mathrm{O}$ & $\frac{6.42}{2.32}$ & 6.84 & $\mathrm{Si}$ & - & 0.036 & & & \\
\hline Aliv & 4.629 & 4.586 & 4.698 & $\begin{array}{l}.444 \\
4.556\end{array}$ & 4.652 & & 96.06 & $\overline{97.56}$ & 95.96 & & 93.03 & $\overline{90.56}$ & Al & 11.717 & 11.597 & & & \\
\hline Alvi & 4.139 & 3.894 & 4.158 & 3.910 & 4.652 & & & $23(0)$ & & & & $22(0)$ & Cr & 4.388 & 4.436 & & & \\
\hline $\mathrm{Cr}_{3}$ & 0.480 & 0.667 & 0.521 & 0.599 & 0.690 & & & $23(0)$ & & & & $22(0)$ & $\mathrm{Fe}^{3+}$ & & & & & \\
\hline $\mathrm{Fe}^{3}$. & 0.010 & 0.025 & 0.019 & 0.045 & 0.021 & $\mathrm{Si}$ & 6.323 & 6.432 & 6.424 & Si & 5.688 & 5.623 & $\mathrm{Mg}$ & 7.123 & 7.097 & & & \\
\hline $\mathrm{Mg}$ & 3.336 & 3.398 & 3.269 & 3.445 & 3.274 & Aliv & 1.677 & 1.568 & 1.576 & Aliv & 2.312 & 2.377 & $\mathrm{Fe}^{2+}$ & 0.718 & 0.746 & & & \\
\hline $\mathrm{Fe}^{2}$. & 0.039 & 0.029 & 0.029 & 0.023 & 0.069 & Alvi & 1.193 & 1.182 & 1.135 & Alvi & 0.535 & 0.688 & $M n$ & & 0.032 & & & \\
\hline \multirow[t]{8}{*}{$\mathrm{Mn}$} & & & 0.013 & & 0.015 & $\mathrm{Cr}$ & 0.130 & 0.135 & 0.093 & $\mathrm{cr}_{\mathrm{r}}$ & 0.106 & 0.079 & & & & & & \\
\hline & & & & & & $T i$ & 0.01 .5 & 0.012 & 0.016 & $\pi i$ & 0.113 & 0.071 & & & & & & \\
\hline & & & & & & $\mathrm{Fe}^{2+}$ & 0.147 & $\begin{array}{l}0.137 \\
0.015\end{array}$ & 0.152 & $\begin{array}{l}\mathrm{Fe}^{2+} \\
\mathrm{Ni}\end{array}$ & 0.062 & 0.064 & & & & & & \\
\hline & & & & & & $\mathrm{Mg}$ & 3.515 & $\begin{array}{l}0.010 \\
3.519\end{array}$ & 3.604 & $\mathrm{Mg}$ & 5.205 & 5.059 & & & & & & \\
\hline & & & & & & $\begin{array}{l}M g \\
M g\end{array}$ & $\begin{array}{l}3.515 \\
1.934\end{array}$ & 1.838 & $\begin{array}{l}1.604 \\
1.905\end{array}$ & $\mathrm{Ca}$ & 0.015 & $\begin{array}{l}0.059 \\
0.014\end{array}$ & & & & & & \\
\hline & & & & & & $\mathrm{Ca}$ & 0.069 & 0.094 & 0.082 & $\mathrm{Na}$ & 0.228 & 0.263 & & & & & & \\
\hline & & & & & & $\mathrm{Na}$ & - & 0.068 & 0.013 & $k$ & 1.142 & 1.255 & & & & & & \\
\hline & & & & & & $\mathrm{Na}$ & 0.316 & 0.311 & 0.328 & & & & & & & & & \\
\hline
\end{tabular}

Sample GGU 149434.
$t$ All $\mathrm{Fe}$ calculated as $\mathrm{FeO} . \mathrm{Fe}^{3+}$ has been calculated by allocating the ions stoichiometrically according to the methods of Higgins at al. (1979). nhe assistance of J.V.P. Long and $\mathrm{P}$. Treloar at the Department of Earth Scierces at Cambridge University is gratefully acknowledged. 
Hughes, 1977). In sapphirine sites which can become available for occupation by $\mathrm{Cr}^{3+}$ may be created by an $\mathrm{Al}^{3+}$ to $\mathrm{Cr}^{3+}$ substitution during the formation of the sapphirine.

This detailed mineralogical work on reaction rocks produced at the contact of the anorthosite complex provides corroborative evidence for conditions of high water vapour pressure during the crystallisation history of the Fiskenæsset anorthosite complex.

\section{References}

Friend, C. R. L. \& Hughes, D. J. 1977: Archaean aluminous ultrabasic rocks with primary igneous textures from the Fiskenæsset region, southern West Greenland. Earth planet. Sci. Lett. 36, 157-167. Ghisler, M. \& Windley, B. F. 1967: The chromite deposits of the Fiskenæsset region, West Greenland. Rapp. Grønlands geol. Unders. 12, $39 \mathrm{pp}$.

Higgins, J. B., Ribbe, P. H. \& Herd, R. K. 1979: Sapphirine 1. Crystal chemical contributions. Contr. Miner. Petr. 68, 349-356.

Leake, B. E. 1978: Nomenclature of amphiboles. Mineralog. Mag. 42, 553-563.

Shiraki, K. 1966: Some aspects of the geochemistry of chromium. J. Earth Sci. 14(1), 10-55.

Wager, L. R. \& Brown, G. M. 1968: Layered Igneous Rocks. Edinburgh \& London: Oliver \& Boyd. Windley, B. F., Herd, R. K. \& Bowden, A. A. 1973: The Fiskenæsset complex, West Greenland. Part I. A preliminary study of the stratigraphy, petrology and whole-rock chemistry from Qeqertarssuatsiaq. Bull. Grønlands geol. Unders. 106, 80 pp.

\section{Thorium-uranium mineralisation in the vicinity of the Igdlerfigssalik centre of the Igaliko Complex, South Greenland}

\section{Agnete Steenfelt and Tapani Tukiainen}

The existence of radioactive rocks in the area south of the Igdlerfigssalik centre of the Igaliko nepheline syenite complex has been known since 1962 (S. Andersen, personal communication). Reconnaissance radiometric investigations on the ground and from a helicopter in 1979 and 1980 revealed a large number of occurrences of radioactive mineralisation. The characteristics of the mineralisation are briefly described.

\section{Geology}

The area is underlain by the Proterozoic 'Julianehåb Granite' (1810-1770 m.y.; van Breemen et al., 1974) which during the Gardar period (1330-1150 m.y.; Emeleus \& Upton, 1976) was faulted and intruded by numerous ENE-trending dykes, and the emplacement of 